\title{
Optimising the quarantining and response sequence towards SARS-CoV-2 outbreaks on board cargo
}

\section{vessels}

Kok Yew Ng, $\mathrm{PhD}^{1,5, *}$, Tudor A Codreanu, MD, $\mathrm{PhD}^{2,3, *}$, Meei Mei Gui, $\mathrm{PhD}^{4}$, Pardis Biglarbeigi, $\mathrm{PhD}^{1}$, Dewar Finlay, $\mathrm{PhD}^{1}$, and James McLaughlin, $\mathrm{PhD}^{1}$

${ }^{1}$ Engineering Research Institute, Ulster University, Shore Road, BT37 0QB, Newtownabbey, U.K.

${ }^{2}$ State Health Incident Coordination Centre, Department of Health Western Australia, Perth, Western Australia, Australia

${ }^{3}$ Disaster Preparedness and Management Unit, Divisional Commander, Complex Medical Deployments, Department of Health Western Australia, Perth, Western Australia, Australia.

${ }^{4}$ School of Chemistry and Chemical Engineering, Queen's University Belfast, David Keir Building, Stranmillis Road, BT9 5AG, Belfast, U.K.

${ }^{5}$ Electrical and Computer Systems Engineering, School of Engineering, Monash University, Bandar Sunway, 47500, Selangor, Malaysia.

${ }^{*}$ Corresponding authors: Ng KY and Codreanu TA contributed equally to this work. Emails: mark.ng@ulster.ac.uk, tudor.codreanu@health.wa.gov.au 
medRxiv preprint doi: https://doi.org/10.1101/2021.11.03.21265201; this version posted November 5, 2021. The copyright holder for this preprint (which was not certified by peer review) is the author/funder, who has granted medRxiv a license to display the preprint in

All rights reserved. No reuse allowed without permission.

\begin{abstract}
The Coronavirus Disease (COVID-19) pandemic has brought significant impact onto the maritime activities worldwide, including disruption to global trade and supply chains. The ability to predict the evolution and duration of a COVID-19 outbreak on cargo vessels would inform a more nuanced response to the event and provide a more precise return-to-trade date. A SEIQ(H)R (Susceptibility-ExposedInfected-Quarantine-(Hospitalisation)-Removed/Recovered) model is developed and fit-tested to simulate the transmission dynamics of COVID-19 on board cargo vessels of up to 60 crew. Due to specific living and working circumstances on board cargo vessels, instead of utilising the reproduction number, we consider the crew members from the same country to quantify the transmission of the disease. The performance of the model is verified using case studies based on data collected during COVID-19 outbreaks on three cargo vessels in Western Australia during 2020. The convergence between simulation results and the data verifies the performance of the model. The simulations show that the model can forecast the time taken for the transmission dynamics on each vessel to reach their equilibriums, providing informed predictions on the evolution of the outbreak, including hospitalisation rates and duration. The ability to model the evolution of an outbreak, both in duration and severity, is essential to predict outcomes and to plan for the best response strategy. At the same time, if offers a higher degree of certainty regarding the return to trade, which in turn is of significant importance to multiple stakeholders.
\end{abstract}

Keywords: COVID-19, Coronavirus, Compartmental model, Mathematical modelling, Cargo vessels, Western Australia 
medRxiv preprint doi: https://doi.org/10.1101/2021.11.03.21265201; this version posted November 5, 2021. The copyright holder for this preprint (which was not certified by peer review) is the author/funder, who has granted medRxiv a license to display the preprint in

All rights reserved. No reuse allowed without permission.

\section{Introduction}

Since the declaration of the Coronavirus Disease 2019 (COVID-19) pandemic by the World Health Organisation (WHO) [1, merchant vessels worldwide have been affected by Severe Acute Respiratory Syndrome Coronavirus 2 (SARS-CoV-2) outbreaks and ports remain a high-risk entry point for the infection [2, 3, 4]. The spread of infectious diseases among crew on board cargo vessels is facilitated by several factors including a high population density in frequent direct contact areas, sharing of general amenities on board [2, 5], and interactions with shore-based maritime workers. Risk mitigation through international sanitation legislation requirements [6, 7, 8, 9, 10] and the measures mandated under the International Health Regulations [2, 11, 12, 13] have decreased the transmissions of SARS-CoV-2 [2, 4, 11], but were unable to fully control outbreaks on board [3, 4, 14].

Unlike cruise ships that can accommodate very large numbers of passengers and crew 4], cargo vessels operate with a comparatively much fewer crew [2], and a different work and social interaction pattern. Granting of pratique is based on providing objective and subjective data of the situation on board prior to arrival, of which assessment could be misleading [3]. The declaration of an outbreak on board a cargo vessel has implications not only for the crew, but also for the vessel owner, shipping agent, operator, flag state, trade partners, and incident response agencies. Notwithstanding the threat to the crew's health [4, 15], outbreak management not only has significant logistic and economic impact on the response agencies, but also on maritime transport and trade [2, 16. In addition, the containment measures (quarantine, isolation, and sanitation), travel restrictions, and border closures [17] continue to make it increasingly difficult for ship operators worldwide to be granted pratique [18, 19], conduct trade, and change crew [20].

The continuous advancement of knowledge on the clinical outcomes of COVID19 and the role of associated factors such as age, co-morbidities, and ethnicity [21, 22] should underpin a more nuanced approach to managing outbreaks on cargo vessels in order to minimise the impact on crew health, maritime traffic, and trade. As a result, mathematical models can be used to provide an accurate and dynamic prediction of a COVID-19 outbreak progression in this setting. 
medRxiv preprint doi: https://doi.org/10.1101/2021.11.03.21265201; this version posted November 5, 2021. The copyright holder for this preprint (which was not certified by peer review) is the author/funder, who has granted medRxiv a license to display the preprint in

All rights reserved. No reuse allowed without permission.

The Susceptibility-Infected-Removed (SIR) or Susceptibility-Exposed-InfectedRemoved (SEIR) models have been used to model infectious diseases outbreaks [23] in which the epidemic is represented in a series of separate compartments or subpopulations. The SEIR model was used to predict the effectiveness of public health measures to control the COVID-19 outbreak on a passenger cruise ship [11, and a modified SEIR model that includes hospitalisation, quarantine, and isolation was used to model other infectious disease epidemics [24, 25].

Knowledge of the modelled evolution of the COVID-19 outbreak, both in duration and severity, is essential to predict outcomes and to plan for the most efficient and effective response strategies. Based on the Western Australian experience in managing COVID-19 outbreaks on board cargo vessels during 2020, here in this paper we describe the development of a mathematical model that could be used to inform the risk assessment of the population-specific epidemiological parameters for SARS-CoV-2 spread on similar vessels. The generalised SEIQ(H)R model was developed and modified based on previous reported works [24, 25, 26, 27] and represents the epidemic in separate compartments in cascade: susceptibility (S), exposed (E), infected (I), quarantine (Q), hospitalisation $(\mathrm{H})$, and removed/recovered $(\mathrm{R})$. This research is crucial towards the fight against the COVID-19 pandemic as we address the importance of modelling the transmission dynamics of SARS-CoV-2 amongst crew members on board cargo vessels, which has rarely been considered in published works thus far as most of them reported on passenger cruise ships [11, 28, 29].

The remaining of this paper is organised as follows: Section 2 presents the proposed mathematical model; Section 3 describes the data used for the case studies in this paper; Section 4 verifies the model against the data collected and provides some results and discussions from the simulations; Section 5 explains the limitations of the proposed model; and Section 6 concludes the paper. 


\section{Methods}

The SEIQ $(\mathrm{H}) \mathrm{R}$ model was developed utilising quarantine measures, hospitalisations, absence of vaccinations against or confirmed history of previous COVID-19 infections, as well as non-COVID-19-related births and deaths occurring on the vessel. The model can be expressed using

$$
\begin{aligned}
& \dot{p}_{S}=-\beta_{e} p_{S} p_{I}, \\
& \dot{p}_{E}=\beta_{e} p_{S} p_{I}-\alpha p_{E}, \\
& \dot{p}_{I}=\alpha p_{E}-\lambda p_{I}, \\
& \dot{p}_{Q}=\lambda p_{I}+\kappa p_{H}-\omega p_{Q}-\gamma p_{Q}, \\
& \dot{p}_{H}=\omega p_{Q}-\kappa p_{H}, \\
& \dot{p}_{R}=\gamma p_{Q},
\end{aligned}
$$

where $p_{S}, p_{E}, p_{I}, p_{Q}, p_{H}$, and $p_{R}$ represent the susceptible $(\mathrm{S})$, exposed (E), infectious (I), quarantined (Q), hospitalised (H), and removed/recovered (R) subpopulations, respectively. The parameter $\beta_{e}$ denotes the rate of transmission per S-I contact, $\alpha$ the rate of an exposed person becoming infectious, $\lambda$ the rate of which an infectious person is quarantined, $\omega$ the rate of which a quarantined person is hospitalised, $\gamma$ the rate of which a quarantined person recovers, and $\kappa$ is the rate of which a hospitalised person is discharged and completes their quarantine. Hence, the incubation time can be written as $\tau_{i n c}=1 / \alpha$, the time from onset to being quarantined is $\tau_{i n f Q}=1 / \lambda$, the time spent in quarantine before recovery is $\tau_{\text {quarR }}=1 / \gamma$, the time spent in quarantine before being hospitalised is $\tau_{\text {quar } H}=1 / \omega$, and the hospitalisation time is $\tau_{\text {hosp }}=1 / \kappa$. It is also established that the total number of crew members on the vessel, $p_{N}$, can be computed such that $p_{N}=p_{S}+p_{E}+p_{I}+p_{Q}+p_{H}+p_{R}$.

Given the crew size, the transmission dynamics and spread of the infectious disease cannot be accurately quantified using the reproduction number that is applied to studies involving large populations, i.e. a country or a geographical region. Thus, instead of using the parameter $\beta_{e}$ (or its equivalent mathematical representation 
medRxiv preprint doi: https://doi.org/10.1101/2021.11.03.21265201; this version posted November 5, 2021. The copyright holder for this preprint (which was not certified by peer review) is the author/funder, who has granted medRxiv a license to display the preprint in

All rights reserved. No reuse allowed without permission.

in other existing models) to compute the reproduction number [24, 25, 26, 27], its purpose here is to inform the transmission dynamics of SARS-CoV-2 by considering the majority of crew members from the same country. This information is estimated critical as crew who originate from the same country often share similar language and culture, thus have increased social interactions on board, which in turn would reasonably be expected to increase the rate of transmission. Therefore, $\beta_{e}$ can be expressed using

$$
\beta_{e}=k m_{p}
$$

where $m_{p}$ represents the highest fraction of crew who originate from the same country and $k$ is a scalar coefficient. Figure 1 shows the block diagram of the SEIQ(H)R model in equations (1)-(6).

[Figure 1 about here.]

\section{Data Sources}

The data used are based on the records of COVID-19 outbreaks declared on the cargo vessels MV Al Kuwait, MV Al Messilah, and MV Patricia Oldendorff during 2020 in Western Australia.

The data collection, analysis, storage, and reporting were conducted in line with the WHO Ethical Standards for Research During Public Health Emergencies (COVID-19), the WHO Guidance for Managing Ethical Issues in Infectious Diseases Outbreaks, and the WHO Guidelines on Ethical Issues in Public Health Surveillance. Ethics approval was not required for this investigation as it was conducted as part of the public health response to the outbreaks of COVID-19, which is a notifiable infectious disease under the Western Australia Public Health Act 2016. The release of data not already in the public domain has been granted by the Western Australia Department of Health Public Health Emergency Operations Centre Data Custodian. The Western Australian Department of Health Human Research Ethics Committee (HREC) has determined that the routine public health investigative work relating to a series of outbreaks of infectious disease that involved aggregate data, in accordance with section 5.1 .8 of the National Statement, involves 
medRxiv preprint doi: https://doi.org/10.1101/2021.11.03.21265201; this version posted November 5, 2021. The copyright holder for this preprint (which was not certified by peer review) is the author/funder, who has granted medRxiv a license to display the preprint in

All rights reserved. No reuse allowed without permission.

only negligible risk (i.e. where there is no foreseeable risk or harm or discomfort, and any foreseeable risk is no more than inconvenience) and therefore does not need to be reviewed by the HREC.

\section{Results and Discussion}

In aggregate, 66 out of 122 crew (10 nationalities) were diagnosed with COVID-19 $(54.10 \%)$, and three $(4.55 \%)$ of the cases required hospitalisation, but not mechanical ventilatory support. Table 1 summarises the data from the three vessels (additional data are provided in the Supplementary Data).

[Table 1 about here.]

Simulations to verify the model were carried out using MATLAB/Simulink R2021a. Given the data in Table 1, the parameter $m_{p}$ in equation (7) was set to the majority of the crew members of the same nationality, i.e. 0.67 for $\mathrm{MV} \mathrm{Al}$ Kuwait, 0.70 for MV Al Messilah, and 0.95 for MV Patricia Oldendorff, respectively. Through experimentations, the coefficient $k$ was set to 1.15 for all vessels. To ensure that the model can be generalised, and based on the records in the Supplementary Data, we set the remaining parameters of the model in equations (1)-(6) as follows:

- $\alpha=\lambda=1 / 5$, assuming that it takes the population about 5 days to progress from $\mathrm{E}$ to I, and I to Q, respectively.

- $\gamma=0.95 \times 1 / 15$, assuming that $95 \%$ of those in quarantine would recover after about 15 days.

- $\omega=0.05 \times 1 / 2$, assuming that $5 \%$ of those in quarantine would be hospitalised after about 2 days.

- $\kappa=1 / 2$, assuming that those hospitalised would take about 2 days before being discharged and return to being quarantined.

The convergence between the results of the proposed model and the observed data for each vessel are presented in Figure 2, The simulations can forecast the time for the transmission dynamics on each vessel to reach their equilibriums, hence providing informed predictions on the evolution of the outbreak on board that would 
medRxiv preprint doi: https://doi.org/10.1101/2021.11.03.21265201; this version posted November 5, 2021. The copyright holder for this preprint (which was not certified by peer review) is the author/funder, who has granted medRxiv a license to display the preprint in

All rights reserved. No reuse allowed without permission.

be useful to determine if and when the vessel can be granted pratique to conduct trade and crew exchange. The model demonstrates that all crew members should be considered susceptible to infection and that, if left unmitigated, the transmission of the infection on board can (a) affect the entire crew, potentially crippling the safety and security of the vessel by breaching the mandated Minimum Safe Manning [2], and (b) continue for many weeks, contrary to estimations declared by some operators [3].

[Figure 2 about here.]

The very low number and short duration of hospital admissions could reflect the relative absence of pre-existing health risk factors in the individuals affected, which supports a nuanced approach to the management of the outbreak. However, the risks of severe disease and death are not null, and a clinical deterioration at sea can have catastrophic consequences to the individuals, the larger crew, and the vessel. This is further complicated by the default absence of medical facilities, monitoring equipment, and qualified medical personnel on board cargo vessels.

It was also found that crew members' roles on board is a determining factor in the evolution of the outbreak (Figure 3). This could be due to the characteristics of the accommodation structure on cargo vessels that include common predicted intersection points (mess rooms and catering staff, as well as shared facilities such as showers and toilets) irrespective of the technical segregation between officers and ratings, in both the deck and engine groups.

[Figure 3 about here.]

\section{$5 \quad$ Limitations}

The proposed model fits the data collected during the management of COVID-19 outbreaks on board three cargo vessels in Western Australia, albeit is limited to a typical cargo vessel crew size. More data is required to ascertain that the observed model and data convergence can be generalised to larger crew sizes. The model has not been calibrated for complex individualist versus collectivist cultural 
medRxiv preprint doi: https://doi.org/10.1101/2021.11.03.21265201; this version posted November 5, 2021. The copyright holder for this preprint (which was not certified by peer review) is the author/funder, who has granted medRxiv a license to display the preprint in

All rights reserved. No reuse allowed without permission.

aspects of the crews nor for social interaction patterns on board as these are largely superseded by clear hierarchical command and control relationships as well as intersection points. Therefore, further division of the crew in subclasses of susceptible individuals has not been deemed necessary as it is not expected to alter the modelling.

Also, vaccines against SARS-CoV-2 were not available at the time of the study. The model does not consider individual's past COVID-19 illness as quality information is usually not available at the time of the outbreak declaration. Since gathering and verifying the crew's previous COVID-19 infection data may prove logistically challenging where reliable information is lacking, serological determination may be required that prolongs the timeline to verification. Further refining of the model could be undertaken by incorporating emerging evidences regarding the protection to SARS-CoV-2 (re)infection in vaccinated individuals.

\section{Conclusion}

COVID-19 outbreaks on cargo vessels continue to present significant economic, trade, and health impacts to countries worldwide. The ability to model the evolution of an outbreak on board typical crew-sized cargo vessels, both in duration and severity, is essential to predict outcomes and to plan for the best response strategies. The proposed SEIQ $(\mathrm{H}) \mathrm{R}$ model has provided a good fit for the outbreaks on three cargo vessels in Western Australia in 2020. Further research is required to determine its generalisability onto other classes and categories of cargo vessels, whilst also focussing on new and emerging SARS-CoV-2 variants, as well as previous COVID-19 disease and/or vaccination status.

\section{Statements and Declarations}

There is NO Competing Interest. 
medRxiv preprint doi: https://doi.org/10.1101/2021.11.03.21265201; this version posted November 5, 2021. The copyright holder for this preprint (which was not certified by peer review) is the author/funder, who has granted medRxiv a license to display the preprint in

All rights reserved. No reuse allowed without permission.

\section{Author Contributions Statement}

Codreanu TA and Ng KY conceived the study. Ng KY and Gui MM developed the model and ran the analysis. Biglarbeigi $\mathrm{P}$ provided further visualisations and data analysis. Ng KY, Gui MM, and Codreanu TA wrote the first draft. Finlay D and McLaughlin J provided critical feedback and reviewed the manuscript. All authors read and approved the manuscript.

\section{$9 \quad$ Funding}

The authors received no funding for this work.

\section{Acknowledgments}

To the crew and Masters of the vessels MV Al Kuwait, MV Al Messilah, MV Patricia Oldendorff, and MV Key Integrity — our heartfelt and sincere recognition for your compliance during the challenges of quarantine.

The authors would also like to acknowledge the contributions of the representatives of the following State agencies who have made possible the execution of the Western Australian State COVID-19 outbreak quarantine sequence on board these vessels: Western Australian Department of Health, Western Australian Medical Assistance Team, Australian Border Force, Western Australian Police Force, Department of Fire and Emergency Services, Fremantle Port, Pilbara Port, Western Australian Country Health Services, PathWest, Royal Flying Doctor Service, Australian Defence Force, Australian Maritime Safety Authority, Department of Agriculture, Water and the Environment, Department of Foreign Affairs and Trade. Special acknowledgments are due to the in-country representatives of the affected vessels (shipping agents).

\section{References}

[1] World Health Organization. WHO announces COVID-19 outbreak a pandemic, 
medRxiv preprint doi: https://doi.org/10.1101/2021.11.03.21265201; this version posted November 5, 2021. The copyright holder for this preprint (which was not certified by peer review) is the author/funder, who has granted medRxiv a license to display the preprint in

All rights reserved. No reuse allowed without permission.

2020.

[2] T A Codreanu, N Pingault, E O'Loughlin, et al. The Healthy Crew, Clean Vessel, and Set Departure Date Triad: Successful Control of Outbreaks of COVID-19 On Board Four Cargo Vessels. Prehospital and Disaster Medicine, 36(5):611-620, 2021.

[3] T A Codreanu and P K Armstrong. Delusions of Certainty: Commercial Vessel COVID-19 Risk Stratification. Prehospital and Disaster Medicine, 36(4):481$485,2021$.

[4] T A Codreanu, S Ngeh, A Trewin, and P K Armstrong. Successful Control of an Onboard COVID-19 Outbreak Using the Cruise Ship as a Quarantine Facility, Western Australia, Australia. Emerging Infectious Diseases, 27(5):12791287, 052021.

[5] World Health Organization. Promoting Public Health Measures in Response to COVID-19 on Cargo Ships and Fishing Vessels. World Health Organization (WHO), Geneva, 2020.

[6] World Health Organization. Guide to Ship Sanitation. World Health Organization (WHO), Geneva, 3rd edition, 2011.

[7] World Health Organization. Handbook for Inspection of Ships and Issuance of Ship Sanitation Certificates. World Health Organization (WHO), Geneva, 2011.

[8] World Health Organization. Handbook for Management of Public Health Events on Board Ships. World Health Organization (WHO), Geneva, 2016.

[9] EU SHIPSAN Act Joint Action. European Manual for Hygiene Standards and Communicable Disease Surveillance on Passenger Ships. Larissa: European Commission Directorate General for Health and Food Safety, 2016.

[10] World Health Organization. International Health Regulations. World Health Organization (WHO), Geneva, 3rd edition, 2005.

[11] J Rocklöv, H Sjödin, and A Wilder-Smith. COVID-19 outbreak on the Diamond Princess cruise ship: estimating the epidemic potential and effectiveness of public health countermeasures. Journal of Travel Medicine, 27(3), 022020. 
medRxiv preprint doi: https://doi.org/10.1101/2021.11.03.21265201; this version posted November 5, 2021. The copyright holder for this preprint (which was not certified by peer review) is the author/funder, who has granted medRxiv a license to display the preprint in

All rights reserved. No reuse allowed without permission.

[12] S Tabata, K Imai, S Kawano, et al. Clinical Characteristics of COVID-19 in 104 People With SARS-CoV-2 Infection on the Diamond Princess Cruise Ship: A Retrospective Analysis. The Lancet Infectious Diseases, 20(9):1043-1050, 2020.

[13] E Nakazawa, H Ino, and A Akabayashi. Chronology of COVID-19 Cases on the Diamond Princess Cruise Ship and Ethical Considerations: A Report From Japan. Disaster Medicine and Public Health Preparedness, 14(4):506-513, 2020.

[14] L J Walker, T A Codreanu, P K Armstrong, et al. SARS-CoV-2 Infections Among Australian Passengers on the Diamond Princess Cruise Ship: A Retrospective Cohort Study. PLOS ONE, 16(9):1-12, 092021.

[15] C C Schlaich, M Oldenburg, and M M Lamshöft. Estimating the Risk of Communicable Diseases Aboard Cargo Ships. Journal of Travel Medicine, 16(6):402-406, 092009.

[16] C Jerome, L A Howard, E Uzel, and J R Androulidakis. Rapid first-stage tests of on-ship infection. WMU Journal of Maritime Affairs, 16(1):89-98, 42017.

[17] Australian Government. Biosecurity Act 2015. 2015.

[18] S Dujarric. Statement Attributable to the Spokesman for the Secretary-General on the Repatriation of Seafarers. United Nations Secretary-General, New York, 2015.

[19] Australian Government Department of Health. Traveller with Illness Checklist: Air and Sea Travellers. 2020.

[20] Australian Government Department of Agriculture Water and Environment. 46-2020 - Changes to a Human Health Pre-Arrival Question in the Maritime Arrivals Reporting System (MARS). 2020.

[21] A K Clift, C A C Coupland, R H Keogh, et al. Living Risk Prediction Algorithm (QCOVID) for Risk of Hospital Admission and Mortality From Coronavirus 19 in Adults: National Derivation and Validation Cohort Study. BMJ, 371,2020 . 
medRxiv preprint doi: https://doi.org/10.1101/2021.11.03.21265201; this version posted November 5, 2021. The copyright holder for this preprint (which was not certified by peer review) is the author/funder, who has granted medRxiv a license to display the preprint in

All rights reserved. No reuse allowed without permission.

[22] J Lighter, M Phillips, S Hochman, et al. Obesity in Patients Younger Than 60 Years Is a Risk Factor for COVID-19 Hospital Admission. Clin Infect Dis, 71(15):896-897, 042020.

[23] W O Kermack and A G McKendrick. A contribution to the mathematical theory of epidemics. Proceedings of the Royal Society of London A, 115(772):700$721,1927$.

[24] M A Safi and A B Gumel. Global Asymptotic Dynamics of a Model for Quarantine and Isolation. Discrete and Continuous Dynamical Systems - B, 14(1):209, 2010.

[25] M A Safi and A B Gumel. Mathematical Analysis of a Disease Transmission Model with Quarantine, Isolation and an Imperfect Vaccine. Computers and Mathematics with Applications, 61(10):3044-3070, 2011.

[26] K Y Ng and M M Gui. COVID-19: Development of a Robust Mathematical Model and Simulation Package with Consideration for Ageing Population and Time Delay for Control Action and Resusceptibility. Physica D: Nonlinear Phenomena, 411:132599, 2020.

[27] T D Do, M M Gui, and K Y Ng. Assessing the Effects of Time-Dependent Restrictions and Control Actions to Flatten the Curve of COVID-19 in Kazakhstan. PeerJ, 9:e10806, 2021.

[28] K Mizumoto and G Chowell. Transmission potential of the novel coronavirus (COVID-19) onboard the diamond Princess Cruises Ship, 2020. Infectious Disease Modelling, 5:264-270, 2020.

[29] K Mizumoto, K Kagaya, A Zarebski, and G Chowell. Estimating the asymptomatic proportion of coronavirus disease 2019 (COVID-19) cases on board the Diamond Princess cruise ship, Yokohama, Japan, 2020. Eurosurveillance, 25(10), 2020. 
medRxiv preprint doi: https://doi.org/10.1101/2021.11.03.21265201; this version posted November $5,2021$. The copyright holder for this preprint (which was not certified by peer review) is the author/funder, who has granted medRxiv a license to display the preprint in perpetuity.

All rights reserved. No reuse allowed without permission.

\section{List of Figures}

1 The block diagram of the SEIQ(H)R model in equations (1)-(6). 15

2 Data and model plots for the S, Q, and $\mathrm{H}$ compartments of vessels A) MV Al Kuwait, B) MV Al Messilah, and C) MV

Patricia Oldendorff. . . . . . . . . . . . . . . . . . . . . 16

3 Cases by crew occupation (officers and ratings) for vessels $\mathrm{A}$ ) MV Al Kuwait, B) MV Al Messilah, and C) MV Patricia Oldendorff. The Catering Ratings are a common intersection point for all vessels. . . . . . . . . . . . . . . . . . . . 17 
medRxiv preprint doi: https://doi.org/10.1101/2021.11.03.21265201; this version posted November $5,2021$. The copyright holder for this preprint (which was not certified by peer review) is the author/funder, who has granted medRxiv a license to display the preprint in perpetuity.

All rights reserved. No reuse allowed without permission.

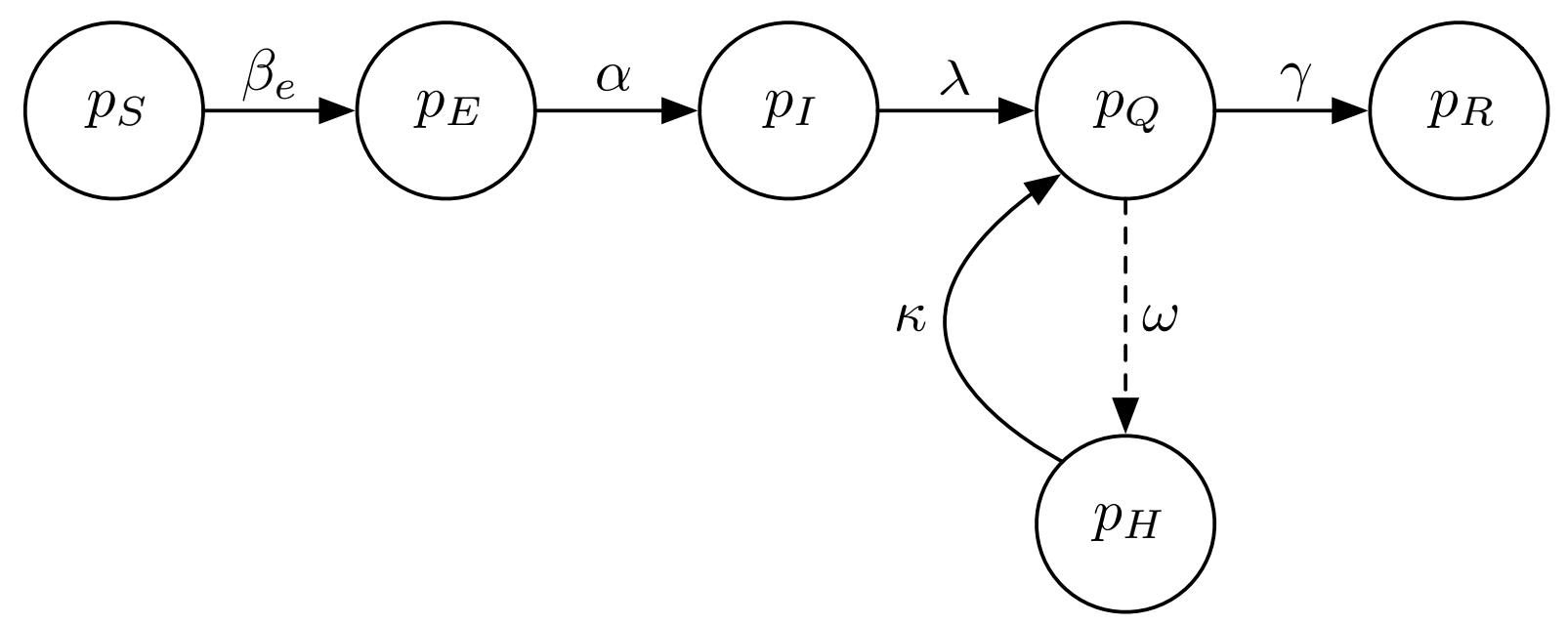

Figure 1: The block diagram of the SEIQ(H)R model in equations (1)-(6). 
medRxiv preprint doi: https://doi.org/10.1101/2021.11.03.21265201; this version posted November 5, 2021. The copyright holder for this preprint (which was not certified by peer review) is the author/funder, who has granted medRxiv a license to display the preprint in All rights reserved. No reuse allowed without permission.
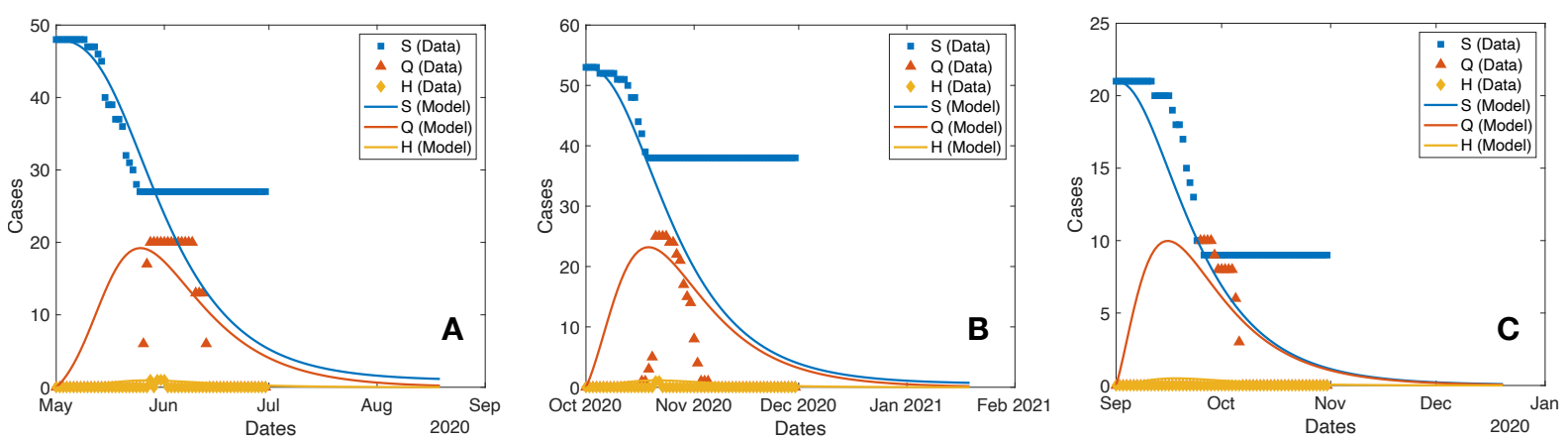

Figure 2: Data and model plots for the S, Q, and $\mathrm{H}$ compartments of vessels A) MV Al Kuwait, B) MV Al Messilah, and C) MV Patricia Oldendorff. 
medRxiv preprint doi: https://doi.org/10.1101/2021.11.03.21265201; this version posted November 5, 2021. The copyright holder for this preprint (which was not certified by peer review) is the author/funder, who has granted medRxiv a license to display the preprint in perpetuity.

All rights reserved. No reuse allowed without permission.
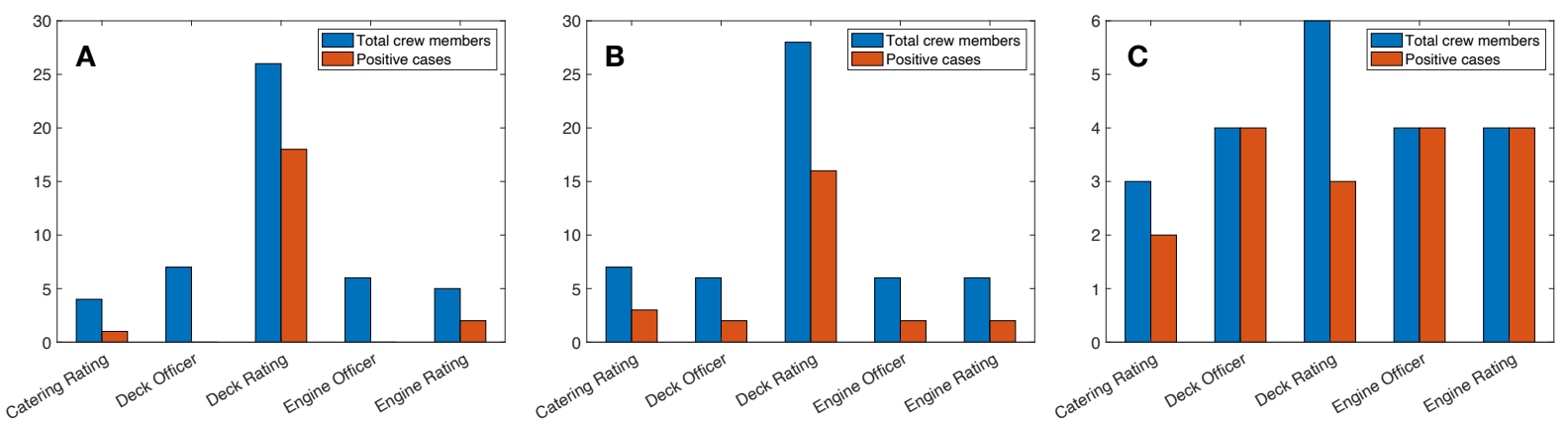

Figure 3: Cases by crew occupation (officers and ratings) for vessels A) MV Al Kuwait, B) MV Al Messilah, and C) MV Patricia Oldendorff. The Catering Ratings are a common intersection point for all vessels. 
medRxiv preprint doi: https://doi.org/10.1101/2021.11.03.21265201; this version posted November 5, 2021. The copyright holder for this preprint (which was not certified by peer review) is the author/funder, who has granted medRxiv a license to display the preprint in All rights reserved. No reuse allowed without permission.

\section{List of Tables}

$1 \quad$ Summarised data of the three vessels. . . . . . . . . . . . . . . 19 
medRxiv preprint doi: https://doi.org/10.1101/2021.11.03.21265201; this version posted November 5, 2021. The copyright holder for this preprint (which was not certified by peer review) is the author/funder, who has granted medRxiv a license to display the preprint in

All rights reserved. No reuse allowed without permission.

Table 1: Summarised data of the three vessels.

\begin{tabular}{ll}
\hline Description & Value \\
\hline Vessel 1: MV Al Kuwait &
\end{tabular}

Total crew members

Crew members by nationalities

\begin{tabular}{lr}
\hline Philippines & $32(66.67 \%)$ \\
Croatia & $10(20.83 \%)$ \\
India & $3(6.25 \%)$ \\
Australia & $2(4.17 \%)$ \\
Tanzania & $1(2.08 \%)$
\end{tabular}

Total confirmed cases 23

Total hospitalised 2

Mean quarantine days $\quad 16.4$

Mean hospitalisation days 2

Vessel 2: MV Al Messilah

Total crew members

Crew members by nationalities

\begin{tabular}{lr}
\hline Bangladesh & $37(69.81 \%)$ \\
India & $7(13.21 \%)$ \\
Sri Lanka & $4(7.54 \%)$ \\
Pakistan & $3(5.66 \%)$ \\
Australia & $1(1.89 \%)$ \\
Syria & $1(1.89 \%)$
\end{tabular}

Total confirmed cases $\quad 25$

Total hospitalised 1

Mean quarantine days $\quad 10.5$

Mean hospitalisation days 2

Vessel 3: MV Patricia Oldendorff

Total crew members

Crew members by nationalities

Philippines

$20(95.24 \%)$

Poland

$1(4.76 \%)$

$\begin{array}{lr}\text { Total confirmed cases } & 18\end{array}$

Total hospitalised 0

Mean quarantine days $\quad 9.8$

Mean hospitalisation days 